\title{
ANALISIS PERTUMBUHAN EKONOMI INKLUSIF KABUPATEN/KOTA DI PROVINSI JAWA TENGAH
}

\author{
Wulan Retno Hapsari \\ Badan Pusat Statistik Kabupaten Karanganyar Provinsi Jawa Tengah \\ wulan.hapsari@bps.go.id
}

\begin{abstract}
High economic growth is not only a means of achieving prosperity, but more than that, high economic growth is one indicator measuring the success of economic development in a region. On the other hand, high economic growth does not guarantee that all people will get the same benefits. Therefore this study was conducted to analyze whether inclusive economic growth has occurred in districts and cities in the province of Central Java. This study uses secondary data sourced from the Central Statistics Agency with coverage of 35 regencies/cities in Central Java Province. Given the variety of definitions and factors used in determining the inclusiveness of economic growth, the researcher decided to adapt the main variables used by the Asian Development Bank $(A D B)$ to measure inclusive economic growth. In the perspective of measuring the quality of economic growth, in addition to looking at the achievements of economic and social indicators in the discussion above, a measure of the quality of economic growth can be seen from the Inclusive Growth Index (IGI). Results of IGI Regencies/Cities in Central Java Province, there are six Regencies /Cities that fall into the very satisfactory category, twenty-five Regencies/Cities fall into the satisfactory category and there are four Regencies in the unsatisfactory category.
\end{abstract}

\section{Keyword: IGI, GRDP, Inclusive Economic Growth}

Abstraksi. Pertumbuhan ekonomi yang tinggi bukan hanya sebagai sarana dalam meraih kesejahteraan, tetapi lebih dari itu, pertumbuhan ekonomi yang tinggi merupakan salah satu indikator pengukur keberhasilan pembangunan ekonomi suatu daerah. Pada sisi lain, pertumbuhan ekonomi yang tinggi tidak menjamin bahwa semua orang akan memperoleh manfaat yang sama. Oleh karena itu penelitian ini dilakukan untuk menganalisis apakah pertumbuhan ekonomi inklusif telah terjadi di kabupaten dan kota di wilayah propinsi Jawa Tengah. Penelitian ini menggunakan data sekunder yang bersumber dari Badan Pusat Statistik dengan cakupan 35 Kabupaten/Kota di Propinsi Jawa Tengah. Mengingat beragamnya definisi dan faktor-faktor yang digunakan dalam menentukan keinklusifan pertumbuhan ekonomi, maka peneliti memutuskan untuk mengadaptasi variable pokok yang digunakan oleh Asian Development Bank (ADB) untuk mengukur pertumbuhan ekonomi inklusif. Dalam perspektif pengukuran kualitas pertumbuhan ekonomi, selain dengan melihat capaian indikator ekonomi dan sosial pada bahasan tersebut di atas, ukuran kualitas pertumbuhan ekonomi bisa dilihat dari Inklusif Growth Index (IGI). Hasil IGI Kabupaten/Kota di propinsi Jawa Tengah terdapat enam Kabupaten/Kota yang masuk dalam kategori sangat memuaskan, dua puluh lima Kabupaten/Kota yang masuk dalam kategori memuaskan dan terdapat empat Kabupaten dalam kategori kurang memuaskan.

Kata kunci: IGI, PDRB, Pertumbuhan Ekonomi Inklusif

\section{PENDAHULUAN}

Pertumbuhan ekonomi didefinisikan sebagai peningkatan kemampuan dari suatu perekonomian dalam mem- produksi barang-barang dan jasa-jasa. Pertumbuhan ekonomi menunjukkan sejauh mana aktivitas perekonomian akan menghasilkan tambahan pendapatan 
masyarakat pada suatu periode tertentu. (Sukirno, 2006)

$$
\text { Pada hakekatnya, pertumbuhan }
$$
ekonomi yang tinggi bukan hanya sebagai sarana dalam meraih kesejahteraan, tetapi lebih dari itu, pertumbuhan ekonomi yang tinggi merupakan salah satu indikator pengukur keberhasilan pembangunan daerah. Selain ditentukan oleh faktor pertumbuhan ekonomi yang tinggi, ukuran keberhasilan pembangunan suatu daerah juga ditentukan dari kemampuan daerah tersebut dalam mengurangi tingkat pengangguran dan kemiskinan, termasuk juga di dalamnya kemampuan menekan kesenjangan antar golongan.

Pada sisi lain, pertumbuhan ekonomi yang tinggi tidak menjamin bahwa semua orang akan memperoleh manfaat yang sama. Untuk memperoleh ukuran yang mampu menjelaskan pertumbuhan ekonomi dan masalah sosial, beberapa lembaga internasional seperti Asian Development Bank (ADB), World Economic Forum (WEF) dan United Nation Development Programme (UNDP) menciptakan suatu set variabel dan formula untuk melakukan pengukuran pertumbuhan ekonomi alternatif yang menekankan pada kesetaraan akses terhadap peluang ekonomi bagi semua lapisan masyarakat. Ukuran ini disebut dengan pertumbuhan ekonomi inklusif.

Menurut ADB (2011), ada beberapa alasan mengapa pertumbuhan harus inklusif yaitu:

1. Pertimbangan kesetaraan dan keadilan, pertumbuhan seharusnya terdistribusi dan inklusif di seluruh lapisan masyarakat dan daerah.

2. Pertumbuhan dengan ketimpangan yang persisten dapat membahayakan kondisi sosial, seperti orang miskin dan pengangguran lebih rentan masuk dalam aktivitas kriminal, perempuan lebih rentan ke prostitusi, dan tenaga kerja anak yang tidak diharapkan.

3. Ketimpangan dalam hasil dan akses yang berkelanjutan dapat mengganggu stabilitas politik dan struktur sosial sehingga mengurangi potensi pertumbuhan yang berkelanjutan.

Menurut Prasetyantoko, dkk (2012), pembangunan ekonomi inklusif adalah Pembangunan untuk semua orang, tidak peduli latar belakang dan perbedaan-perbedaannya. Hal ini senada dengan pendapat Ali dan Son (2007) yang menyatakan bahwa pertumbuhan inklusif adalah pertumbuhan yang tidak hanya menciptakan peluang ekonomi baru, tetapi juga memastikan kesempatan yang sama untuk semua lapisan masyarakat, khususnya yang miskin. Pertumbuhan didefinisikan sebagai inklusif jika meningkatkan fungsi kesempatan sosial, yang tergantung pada dua faktor yaitu: (i) peluang rata-rata yang tersedia bagi masyarakat, dan (ii) bagaimana peluang dibagi kepada masyarakat.

Meskipun telah ada konsensus tentang bagaimana mendefinisikan dan mengukur inklusivitas suatu pertumbuhan, topik ini masih memunculkan perdebatan akademis dan sejumlah pembahasan terkait kebijakan implementasi pembangunan. Sejalan dengan permasalahan ini, maka dalam penulisan ini, dilakukan penghitungan Indeks Pertumbuhan Ekonomi Inklusif atau yang selanjutnya dikenal sebagai Inklusif Growth Index (IGI). Melalui indeks ini, dapat diketahui kualitas pertumbuhan ekonomi yang telah dicapai masing-masing kabupaten/kota di propinsi Jawa Tengah sebagai suatu 
proksi evaluasi keberhasilan pembangunan di wilayah tersebut.

\section{METODE PENELITIAN}

Penelitian ini menggunakan data sekunder yang bersumber dari Badan Pusat Statisik dengan cakupan 35 kabupaten/kota di Provinsi Jawa Tengah. Mengingat beragamnya definisi dan faktor-faktor yang digunakan dalam menentukan keinklusifan pertumbuhan ekonomi, maka peneliti memutuskan untuk mengadaptasi variable pokok untuk mengukur pertumbuhan ekonomi inklusif yang dilakukan oleh ADB. Selain itu, karena data yang tersedia pada level regional tidak selengkap data level nasional, maka modifikasi jenis variabel dilakukan tanpa mengurangi esensi pada definisi yang menjadi acuan. Data tersebut meliputi Laju Pertumbuhan PDRB per kapita (PE_kapita) yang diambil dari publikasi PDRB Lapangan Usaha Propinsi Jawa Tengah Tahun 2014-2018, Persentase Penduduk Miskin (Miskin) yang diambil dari data Susenas Maret 2018, Usia Harapan Hidup (UHH) diambil dari data Susenas Maret 2018, Persentase Penduduk 15+ yang melek huruf $(\mathrm{AMH})$ diambil dari data Susenas Maret 2018, Rata-rata lama sekolah penduduk usia 25+ (RLS) diambil dari data Susenas Maret 2018 dan Tingkat Pengangguran Terbuka (TPT) yang diambil dari Sakernas Februari 2018. Selanjutnya, untuk membuat indeks komposit pertumbuhan ekonomi inklusif (IGI) maka dilakukan tahapan sebagai berikut:

\section{i. Penentuan Bobot Variabel}

Bobot masing-masing variabel ditentukan dengan menggunakan matrik korelasi yang diasumsikan proporsional atau sebanding dengan jumlah nilai absolut koefisien korelasi pada masingmasing baris atau kolom. Penimbang untuk setiap variabel ditentukan dengan menghitung proporsi dari jumlah nilai koefisien korelasi disetiap baris/kolom (variabel) terhadap jumlah keseluruhan. Nilai proporsi tersebut mengindikasikan kontribusi dari setiap variabel dalam memberikan informasi.

Tabel 1: Penentuan Bobot Variabel Pertumbuhan Ekonomi Inklusif

\begin{tabular}{lccrrrrr}
\hline \multicolumn{1}{c}{ Variabel } & PE_kapita & miskin & UHH & AMH & RLS & TPT & Jumlah \\
\hline PE & 1,00 & 0,22 & $-0,05$ & $-0,14$ & $-0,03$ & $-0,02$ & 0,98 \\
miskin & 0,22 & 1,00 & $-0,62$ & $-0,48$ & $-0,64$ & 0,06 & $-0,46$ \\
UHH & $-0,05$ & $-0,62$ & 1,00 & 0,28 & 0,68 & $-0,50$ & 0,79 \\
AMH & $-0,14$ & $-0,48$ & 0,28 & 1,00 & 0,68 & 0,17 & 1,51 \\
RLS & $-0,03$ & $-0,64$ & 0,68 & 0,68 & 1,00 & $-0,07$ & 1,62 \\
TPT & $-0,02$ & 0,06 & $-0,50$ & 0,17 & $-0,07$ & 1,00 & 0,65 \\
\hline Jumlah & 0,98 & $-0,46$ & 0,79 & 1,51 & 1,62 & 0,65 & 5,09 \\
\hline Bobot $(W i)$ & 0,19 & $-0,09$ & 0,16 & 0,30 & 0,32 & 0,13 & 1,00 \\
\hline
\end{tabular}

ii. Normalisasi Data Awal

Mengingat satuan dari variabel atau indikator yang digunakan dalam pengukuran IGI berbeda-beda, maka dilakukan normalisasi data ke dalam skala antara 0 dan 10. Selain itu, 
mengingat adanya perbedaan sifat indikator terhadap pertumbuhan ekonomi (positif atau negatif), maka dalam rumus normalisasi data awal, dilakukan treatment-treatment yang berbeda. Untuk jelasnya, rumus yang digunakan adalah sebagai berikut:

a. Untuk variabel yang mempunyai hubungan positif dengan pertumbuhan ekonomi:

$$
Z_{i j}=10\left[\frac{X_{i j k}-X_{i j(\min )}}{X_{i j(\max )}-X_{i j(\min )}}\right]
$$

b. Untuk variabel yang mempunyai hubungan negatif dengan pertumbuhan ekonomi:

$$
Z_{i j}=-10\left[\frac{X_{i j k}-X_{i j(\min )}}{X_{i j(\max )}-X_{i j(\min )}}\right]+10
$$

iii.Penghitungan Indeks Pertumbuhan Ekonomi Inklusif (IGI)

Setelah data awal dinormalisasi, berikutnya dilakukan penghitungan Indeks Pertumbuhan Ekonomi Inklusif dengan cara menjumlahkan nilai seluruh variabel yang telah dikalikan dengan bobot masing-masing variabel.

$$
I G I=\sum_{i=1}^{n} Z_{i j} W_{i}
$$

iv. Penentuan Capaian

Untuk masing-masing indikator akan diberi skor, berdasarkan performa capaiannya. Pembentukan skor dibuat menjadi 3 capaian yaitu tidak memuaskan $(<4)$, memuaskan (4-7), dan sangat memuaskan (8-10).

\section{PEMBAHASAN}

Pertumbuhan inklusif sering dimaknai sebagai pertumbuhan ekonomi yang difokuskan pada penciptaan peluang ekonomi dan dapat diakses oleh semua (Ali dan Zhuang 2007). Menurut Chakrabarty (2009), pendekatan pertumbuhan yang inklusif mengambil perspektif jangka panjang. Oleh karena itu, pertumbuhan inklusif seharusnya bersifat inheren, berkelanjutan, serta mengurangi kesenjangan antara miskin dan kaya. Pertumbuhan inklusif memungkinkan setiap individu untuk berkontribusi dan mendapatkan manfaat dari pertumbuhan ekonomi.

Strategi pencapaian pertumbuhan yang inklusif dapat dicapai melalui beberapa cara, antara lain percepatan pertumbuhan yang dibarengi dengan pemerataan pertumbuhan, menghilangkan ketimpangan dengan menjamin kesetaraan terhadap peluang, peningkatan jumlah tenaga kerja produktif, penguatan kapasitas produksi, dan juga mewujudkan sistem perlindungan sosial (social safety nets). 


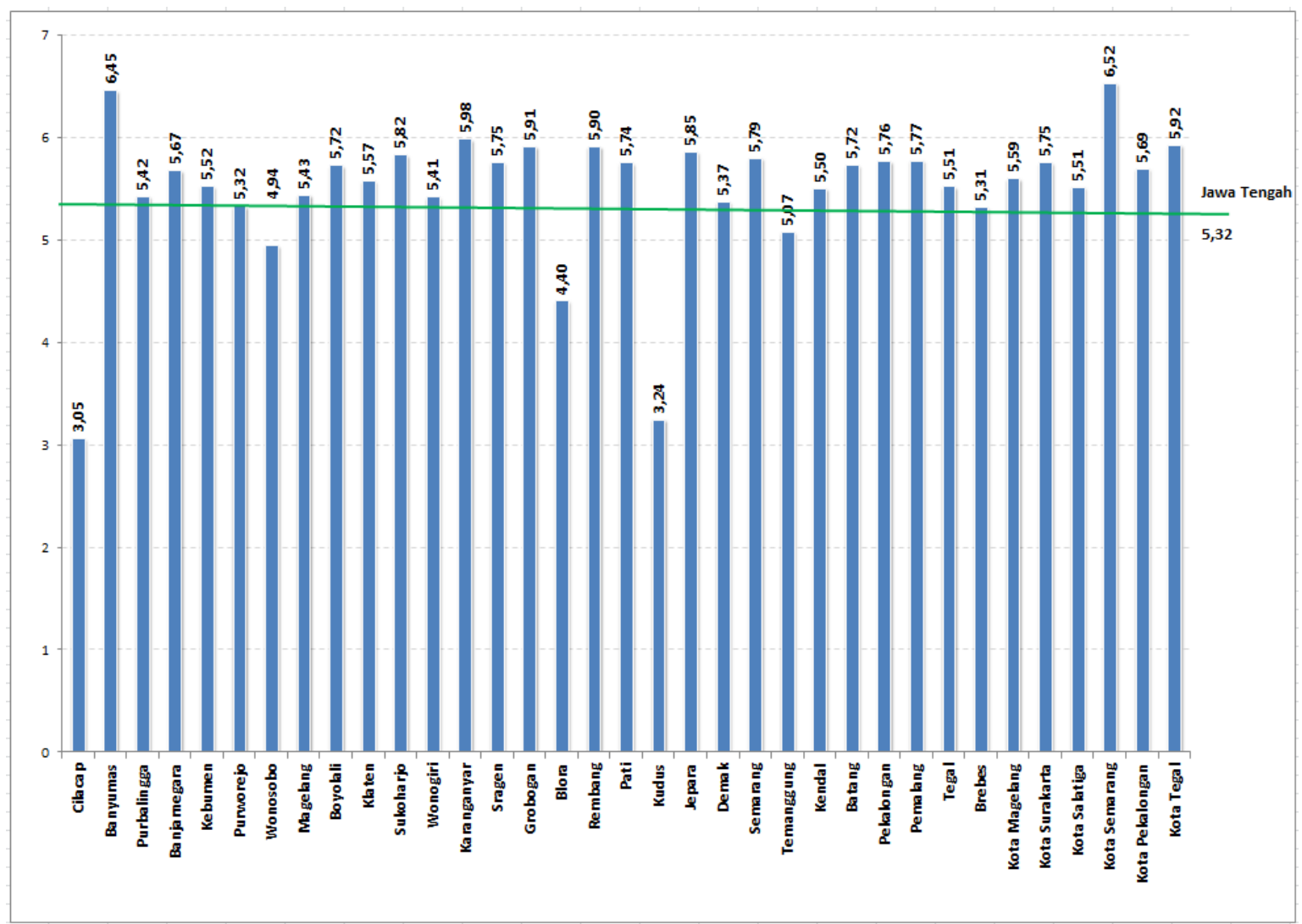

Gambar 1: Laju Pertumbuhan Ekonomi Kabupaten/Kota di Jawa Tengah 2018

1. Pendapatan per Kapita

Produk Domestik Regional Bruto (PDRB) merupakan nilai tambah bruto seluruh barang dan jasa yang tercipta atau dihasilkan di wilayah domestik suatu negara yang timbul akibat berbagai aktivitas ekonomi dalam suatu periode tertentu tanpa memperhatikan apakah faktor produksi yang dimiliki residen atau non-residen. PDRB atas dasar harga berlaku atau dikenal dengan PDRB nominal disusun berdasarkan harga yang berlaku pada periode penghitungan, dan bertujuan untuk melihat struktur perekonomian. Sedangkan PDRB atas dasar harga konstan disusun berdasarkan harga pada tahun dasar dan bertujuan untuk mengukur pertumbuhan ekonomi. Pada tahun 2018 nilai PDRB atas dasar harga berlaku paling tinggi di Kota Semarang yang mencapai 174 triliun rupiah dan terendah di Kota Magelang sebesar 8 triliun rupiah. Untuk PDRB atas dasar harga konstan nilai tertinggi juga berada di Kota Semarang yang tercatat sebesar 131 triliun rupiah dan terendah di Kota Magelang sebesar 6 triliun rupiah.

Pertumbuhan ekonomi merupakan salah satu indikator makro untuk melihat kinerja perekonomian secara riil di suatu wilayah. Laju pertumbuhan ekonomi dihitung berdasarkan perubahan PDRB atas dasar harga konstan tahun yang bersangkutan terhadap tahun sebelumnya. Pertumbuhan ekonomi dapat dipandang sebagai pertambahan jumlah barang dan jasa yang dihasilkan oleh kegiatan ekonomi yang ada di suatu wilayah selama kurun waktu setahun. Laju Pertumbuhan Ekonomi tertinggi pada tahun 2018 berada di Kota Semarang sebesar 6,52 persen sementara terendah tercatat di Kabupaten Cilacap (3,05\%). 
Tabel 2: Laju Pertumbuhan PDRB per Kapita, Angka Kemiskinan, Usia Harapan Hidup, Angka Melek Huruf, Rata-rata Lama Sekolah dan Tingkat Pengangguran Terbuka Menurut Kabupaten/Kota Tahun 2018

\begin{tabular}{|c|c|c|c|c|c|c|c|}
\hline No & Kabupaten/Kota & $\begin{array}{c}\mathrm{PE}_{-} \\
\text {kapita }\end{array}$ & miskin & UHH & AMH & RLS & TPT \\
\hline 1 & Cilacap & 2,58 & 11,25 & 73,39 & 93,00 & 6,92 & 7,48 \\
\hline 2 & Banyumas & 5,56 & 13,50 & 73,45 & 94,89 & 7,41 & 4,19 \\
\hline 3 & Purbalingga & 4,42 & 15,62 & 72,98 & 94,92 & 7,00 & 6,06 \\
\hline 4 & Banjarnegara & 5,06 & 15,46 & 73,91 & 90,73 & 6,28 & 4,00 \\
\hline 5 & Kebumen & 5,24 & 17,47 & 73,11 & 95,15 & 7,34 & 5,52 \\
\hline 6 & Purworejo & 5,04 & 11,67 & 74,40 & 93,91 & 7,70 & 4,51 \\
\hline 7 & Wonosobo & 4,51 & 17,58 & 71,46 & 94,20 & 6,75 & 3,44 \\
\hline 8 & Magelang & 4,51 & 11,23 & 73,47 & 95,03 & 7,57 & 2,91 \\
\hline 9 & Boyolali & 5,16 & 10,04 & 75,79 & 90,97 & 7,55 & 2,16 \\
\hline 10 & Klaten & 5,21 & 12,96 & 76,67 & 91,44 & 8,24 & 3,11 \\
\hline 11 & Sukoharjo & 5,01 & 7,41 & 77,54 & 93,53 & 8,84 & 2,78 \\
\hline 12 & Wonogiri & 5,15 & 10,75 & 76,05 & 90,09 & 6,88 & 2,28 \\
\hline 13 & Karanganyar & 5,07 & 10,01 & 77,36 & 93,48 & 8,51 & 2,34 \\
\hline 14 & Sragen & 5,42 & 13,12 & 75,60 & 87,19 & 7,22 & 4,82 \\
\hline 15 & Grobogan & 5,41 & 12,31 & 74,55 & 91,53 & 6,67 & 2,24 \\
\hline 16 & Blora & 4,01 & 11,90 & 74,12 & 88,30 & 6,46 & 3,26 \\
\hline 17 & Rembang & 5,12 & 15,41 & 74,39 & 94,70 & 6,95 & 2,87 \\
\hline 18 & Pati & 5,19 & 9,90 & 75,93 & 91,87 & 7,18 & 3,61 \\
\hline 19 & Kudus & 2,05 & 6,98 & 76,47 & 96,44 & 8,62 & 3,33 \\
\hline 20 & Jepara & 4,37 & 7,00 & 75,71 & 94,69 & 7,43 & 3,78 \\
\hline 21 & Demak & 4,35 & 12,54 & 75,29 & 94,87 & 7,48 & 7,16 \\
\hline 22 & Semarang & 4,46 & 7,29 & 75,62 & 95,00 & 7,88 & 2,28 \\
\hline 23 & Temanggung & 4,18 & 9,87 & 75,47 & 95,23 & 6,94 & 3,24 \\
\hline 24 & Kendal & 4,72 & 9,84 & 74,30 & 93,45 & 7,05 & 6,06 \\
\hline 25 & Batang & 4,85 & 8,69 & 74,56 & 94,61 & 6,62 & 4,23 \\
\hline 26 & Pekalongan & 5,09 & 10,06 & 73,53 & 94,18 & 6,74 & 4,41 \\
\hline 27 & Pemalang & 5,49 & 16,04 & 73,11 & 93,43 & 6,32 & 6,21 \\
\hline 28 & Tegal & 5,24 & 7,94 & 71,28 & 92,36 & 6,70 & 8,45 \\
\hline 29 & Brebes & 4,91 & 17,17 & 68,84 & 89,62 & 6,19 & 7,27 \\
\hline 30 & Kota Magelang & 5,24 & 7,87 & 76,72 & 98,49 & 10,31 & 4,88 \\
\hline 31 & Kota Surakarta & 5,38 & 9,08 & 77,11 & 98,04 & 10,53 & 4,39 \\
\hline 32 & Kota Salatiga & 4,05 & 4,84 & 77,11 & 98,57 & 10,40 & 4,28 \\
\hline 33 & Kota Semarang & 4,83 & 4,14 & 77,23 & 97,91 & 10,51 & 5,29 \\
\hline 34 & Kota Pekalongan & 4,79 & 6,75 & 74,25 & 98,42 & 8,57 & 6,13 \\
\hline 35 & Kota Tegal & 5,53 & 7,81 & 74,30 & 97,41 & 8,30 & 7,94 \\
\hline
\end{tabular}

Sumber: BPS Provinsi Jawa Tengah, 2019 
Salah satu indikator proksi tingkat kemakmuran penduduk di suatu wilayah adalah PDRB per kapita, yaitu hasil bagi antara nilai tambah yang dihasilkan oleh seluruh kegiatan ekonomi dengan jumlah penduduk. Besar kecilnya jumlah penduduk akan mempengaruhi nilai PDRB per kapita, sedangkan besar kecilnya nilai PDRB sangat tergantung pada potensi sumber daya alam dan faktor-faktor produksi yang terdapat di daerah tersebut. PDRB per kapita atas dasar harga konstan pada tahun 2018 tertinggi berada di Kota Semarang yang tercatat sebesar 73,42 juta rupiah dan yang terendah di Kabupaten Pemalang sebesar 13,30 juta rupiah.

Sementara untuk laju pertumbuhan PDRB per kapita atas dasar harga konstan tertinggi tercatat di Kabupaten Banyumas sebesar $5,56 \%$ sedangkan yang terendah di Kabupaten Kudus sebesar $2,05 \%$.

\section{Angka Pengangguran}

Selain indikator pertumbuhan ekonomi. Indikator yang sering digunakan untuk menggambarkan pencapaian pembangunan suatu wilayah adalah indikator sosial. Dari sisi ketenagakerjaan, salah satu indikator yang sering digunakan adalah Tingkat Pengangguran Terbuka (TPT) yaitu persentase jumlah penganggur terbuka terhadap jumlah angkatan kerja. Pada tahun 2018 TPT tertinggi tercatat di Kabupaten Tegal sebesar 8,45 persen sementara terendah di Kabupaten Boyolali dengan TPT tercatat sebesar 2,16 persen. Semakin kecil TPT mencerminkan keberhasilan pembangunan dalam khususnya di bidang ketenagakerjaan.

\section{Kemiskinan}

Indikator sosial berikutnya adalah persentase penduduk yang berada dibawah Garis Kemiskinan. Menurut BPS, kemiskinan adalah ketidak mampuan individu dalam memenuhi kebutuhan dasar minimal untuk hidup layak (baik makanan maupun non makanan). Garis kemiskinan yang ditetapkan oleh BPS adalah jumlah pengeluaran yang dibutuhkan oleh setiap individu untuk dapat memenuhi kebutuhan makanan setara dengan 2100 kalori per orang per hari dan kebutuhan non makanan yang terdiri dari perumahan, pakaian, kesehatan, pendidikan, transportasi, serta aneka barang dan jasa lainnya. Semakin kecil nilai indikator ini bisa diartikan semakin sejahtera wilayah tersebut. Persentase penduduk miskin tertinggi tahun 2018 tercatat di Kabupaten Wonosobo yang mencapai 17,58 persen, sedangkan persentase penduduk miskin terendah di Kota Semarang sebesar 4,14\%.

\section{Usia Harapan Hidup (UHH)}

Usia Harapan Hidup (UHH) adalah rata-rata tahun hidup yang masih akan dijalani oleh seseorang yang telah berhasil mencapai umur tertentu pada suatu tahun tertentu, dalam situasi mortalitas yang berlaku di lingkungan masyarakatnya. Usia Harapan Hidup merupakan alat untuk mengevaluasi kinerja pemerintah dalam meningkatkan kesejahteraan penduduk pada umumnya dan meningkatkan derajat kesehatan pada khususnya. UHH tertinggi pada tahun 2018 berada di Kabupaten Sukoharjo $(77,54)$ sedangkan UHH terendah tercatat di Kabupaten Brebes $(68,84)$. 
5. Angka Melek Huruf (AMH)

Angka Melek Huruf (AMH) adalah proporsi penduduk usia 15 tahun ke atas yang mempunyai kemampuan membaca dan menulis huruf latin dan huruf lainnya. AMH merupakan indikator penting untuk melihat sejauh mana penduduk suatu daerah terbuka terhadap pengetahuan. Nilai AMH tertinggi pada tahun 2018 berada di Kota Salatiga $(98,57 \%)$ sedangkan AMH terendah berada di Kabupaten Sragen $(87,19 \%)$.

\section{Rata-rata Lama Sekolah}

Rata-rata lama sekolah adalah ratarata jumlah tahun yang dihabiskan oleh penduduk berusia 25 tahun ke atas untuk menempuh semua jenis pendidikan formal yang pernah dijalani. Indikator ini dihitung dari variabel pendidikan tertinggi yang ditamatkan dan tingkat pendidikan yang sedang diduduki. Standar UNDP adalah minimal 0 tahun dan maksimal 15 tahun. Rata-rata lama sekolah (mean years of schooling) merupakan indikator yang menunjukkan rata-rata jumlah tahun efektif untuk bersekolah yang dicapai penduduk. Jumlah tahun efektif adalah jumlah tahun standar yang harus dijalani oleh seseorang untuk menamatkan suatu jenjang pendidikan, misalnya tamat SD adalah 6 tahun, tamat SMP adalah 9 tahun dan seterusnya. Perhitungan lama sekolah dilakukan tanpa memperhatikan apakah seseorang menamatkan sekolah lebih cepat atau lebih lama dari waktu yang telah ditetapkan. Kabupaten/kota dengan rata-rata lama sekolah tertinggi terdapat di Kota Surakarta (10,53 tahun). Sementara ada 13 Kabupaten/Kota di Provinsi Jawa Tengah dengan rata-rata lama sekolah 6 tahun (atau baru tamat SD). Kabupaten/Kota dengan rata-rata lama sekolah terendah terdapat di Kabupaten Brebes (6,19 tahun).

\section{Pertumbuhan Ekonomi Inklusif}

Dalam perspektif pengukuran kualitas pertumbuhan ekonomi, selain dengan melihat capaian indikator ekonomi dan sosial pada bahasan tersebut di atas, ukuran kualitas pertumbuhan ekonomi bisa dilihat dari nilai Inclusive Growth Index (IGI). Indeks komposit ini didasarkan dengan metode skoring dan skema penimbang. Skor dibuat menjadi 3 capaian yaitu tidak memuaskan $(<4)$, memuaskan (4-7), dan sangat memuaskan (8-10).

Pada tahun 2018 nilai IGI kabupaten/ kota di provinsi Jawa Tengah berkisar pada level 2,41 - 9,57. Empat kota dan dua kabupaten masuk dalam kategori sangat memuaskan yaitu Kota Surakarta dengan nilai IGI tertinggi $(9,57)$, tiga kota lainnya yang masuk kategori sangat memuaskan berikutnya adalah Kota Magelang $(9,20)$, Kota Semarang $(8,73)$, dan Kota Salatiga (7,25). Dua kabupaten yang masuk dalam kategori sangat memuaskan adalah Kabupaten Karanganyar $(7,25)$ dan Kabupaten Sukoharjo $(7,24)$. Sementara untuk kategori memuaskan dicapai oleh 2 kota dan 23 kabupaten, dengan kisaran nilai IGI antara 4,24 sampai 6,88. Sedangkan sisanya terdapat 4 kabupaten dengan nilai IGI yang masuk kategori kurang memuaskan yaitu Kabupaten Tegal (3,26), Kabupaten Blora $(3,17)$, Kabupaten Cilacap $(2,93)$ dan nilai IGI terendah adalah Kabupaten Brebes $(2,41)$. 


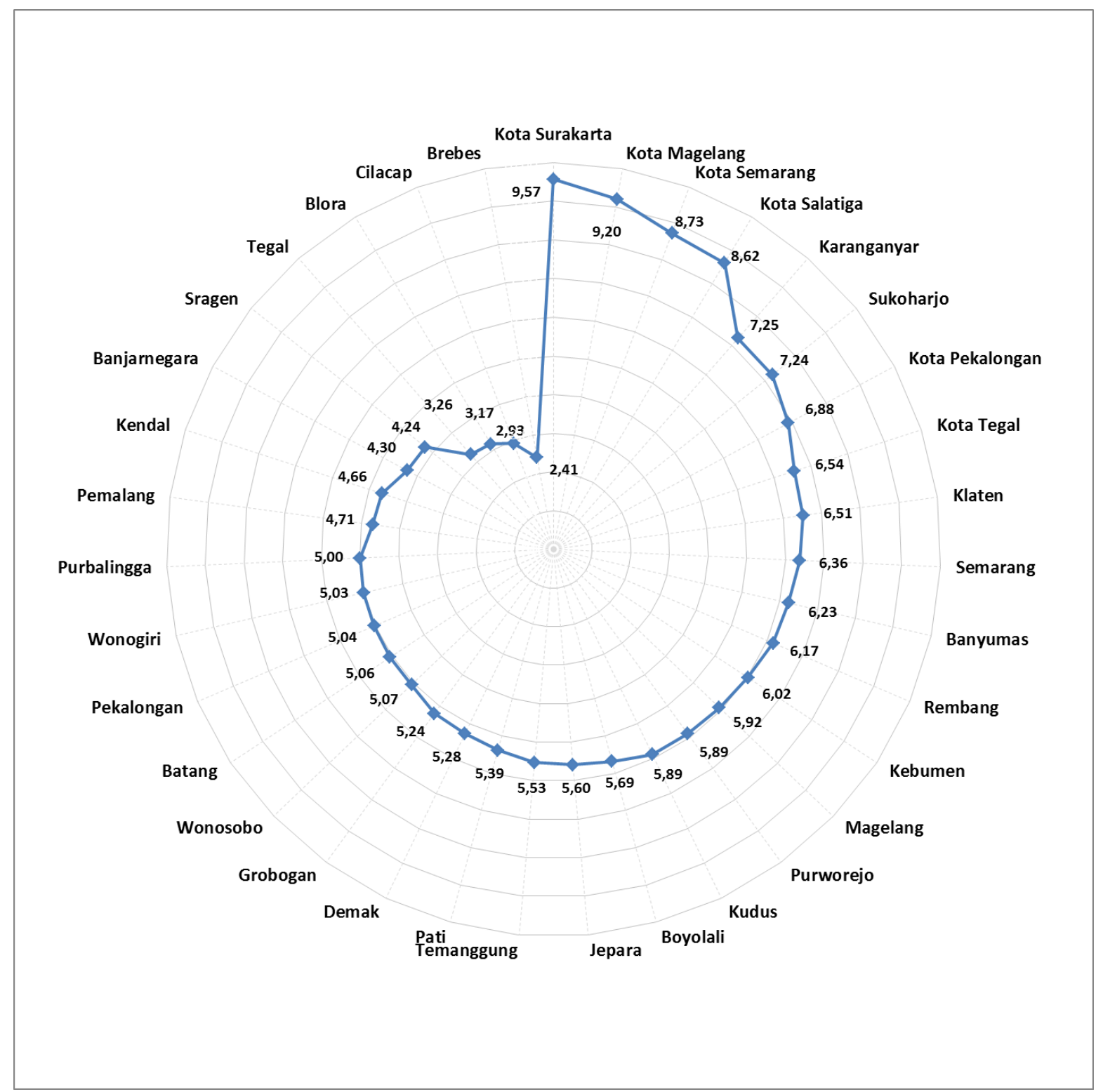

Gambar 2: Inclusive Growth Index (IGI) Kabupaten/Kota di Jawa Tengah 2018

\section{SIMPULAN}

1. Pendekatan keberhasilan pembangunan oleh pemerintah selama ini terlalu berorientasi pada pertumbuhan. Ketika pertumbuhan ekonomi yang tinggi telah tercapai, ternyata permasalahan kemiskinan, pengangguran dan peningkatan kualitas sumber daya manusia tidak serta merta dapat diselesaikan. Kondisi ini yang menyebabkan kualitas pertumbuhan ekonomi dipertanyakan. Paradigma pembangunan ekonomi kedepan seharusnya tidak hanya difokuskan pada pertumbuhan ekonomi yang tinggi semata, tetapi juga harus memperhatikan pembangunan yang bersifat inklusif Kebijakan untuk pertumbuhan yang inklusif adalah komponen penting dari strategi Pemerintah untuk pertumbuhan yang berkelanjutan.

2. Beberapa tahun ini, beberapa metode telah dikemukakan untuk mengukur seberapa besar kualitas pertumbuhan ekonomi yang telah dicapai suatu 
negara atau wilayah. Salah satu indikator yang bisa digunakan untuk mengukur pertumbuhan ekonomi yang inklusif adalah Inclusive Growth Index atau indeks pertumbuhan inklusif.

3. Hasil dari penelitian ini membagi kabupaten/kota di Provinsi Jawa Tengah ke dalam 3 kelompok kategori, yaitu kelompok kategori sangat memuaskan yang terdiri dari 4 kota dan 2 kabupaten, kategori memuaskan terdiri dari 2 kota dan 23 kabupaten, sementara 4 kabupaten masuk ke dalam kategori kurang memuaskan.

4. Inclusive Growth Index ini bisa menjadi salah satu indikator yang dapat dimanfaatkan untuk merumuskan kebijakan pembangunan yang fokus guna mendorong pembangunan yang lebih inklusif. Diharapkan pemerintah daerah dapat memanfaatkan indeks ini sebagai salah satu dasar untuk menetapkan target pembangunan.

\section{DAFTAR PUSTAKA}

Ali, I. And J. Zhuang. 2007. Inklusif Growth toward a Prosperous Asia: Policy Implications. ERD Working Paper Series, No. 97.

Asian Development Bank. (2011). Framework of Inclusive Growth Indicators Key Indicators for Asia and the Pacific 2011 Special Supplement. Phillippines: Asian Development Bank.

Badan Pusat Statistik. (2013). Analisis Pertumbuhan Inklusif 2013. Jakarta: Badan Pusat Statistik.

Badan Pusat Statistik Provinsi Daerah Istimewa Yogyakarta. (2016). Analisis Pertumbuhan Ekonomi Inklusif Daerah Istimewa Yogyakarta 2011-2015. Badan Pusat Statistik Provinsi Daerah Istimewa Yogyakarta.

Badan Pusat Statistik Provinsi Jawa Tengah. Agustus 2019. https://jateng.bps.go.id/subject/157/produk-domestik-regional-bruto--kabupatenkota-.html\#subjekViewTab3. "[Seri 2010] PDRB Atas Dasar Harga Konstan 2010 Menurut Kabupaten/Kota di Jawa Tengah (Juta Rupiah), 2010 - 2018”.

Badan Pusat Statistik Provinsi Jawa Tengah. Agustus 2019. https://jateng.bps.go.id/subject/12/kependudukan.html\#subjekViewTab3. "Jumlah Penduduk Menurut Kabupaten/Kota dan Kelompok Umur Provinsi Jawa Tengah, 2014-2018".

Badan Pusat Statistik Provinsi Jawa Tengah. Agustus 2019. https://jateng.bps.go.id/subject/23/kemiskinan.html\#subjekViewTab3. "Persentase Penduduk Miskin Menurut Kabupaten/Kota di Provinsi Jawa Tengah, 1996-2018”.

Badan Pusat Statistik Provinsi Jawa Tengah. Agustus 2019. https://jateng.bps.go.id/subject/26/indeks-pembangunanmanusia.html\#subjekViewTab3. "[Metode Baru] Usia Harapan Hidup Saat Lahir Jawa Tengah Menurut Kabupaten/Kota (tahun), 2010-2018”. 
Badan Pusat Statistik Provinsi Jawa Tengah. (2019). Keadaan Angkatan Kerja di Provinsi Jawa Tengah Agustus 2018. Badan Pusat Statistik Provinsi Jawa Tengah.

Badan Pusat Statistik Provinsi Jawa Tengah. (2019). Profil Kesehatan Provinsi Jawa Tengah 2018. Badan Pusat Statistik Provinsi Jawa Tengah.

Badan Pusat Statistik Provinsi Jawa Tengah. (2019). Statistik Pendidikan Provinsi Jawa Tengah 2018. Badan Pusat Statistik Provinsi Jawa Tengah.

Badan Pusat Statistik Provinsi Jawa Tengah. (2019). Statistik Sosial Dan Kependudukan Provinsi Jawa Tengah Hasil Susenas 2018. Badan Pusat Statistik Provinsi Jawa Tengah.

Badan Pusat Statistik. (2019). Produk Domestik Regional Bruto Provinsi Jawa Tengah Menurut Lapangan Usaha 2014-2018. Badan Pusat Statistik Provinsi Jawa Tengah.

Boediono. (1985). Teori Pertumbuhan Ekonomi. Yogyakarta : BPFE

McKinley, Terry. 2010. Inklusif Growth Criteria and Indicators: an Inklusif Growth Index for Diagnosis of Country Progress. ADB Sustainable Development Working Paper Series, No. 14. Manila: Asian Development Bank

Prasetyantoko, A., Budiantoro, S., \& Bahagijo, S. (2012). Pembangunan inklusif: prospek dan tantangan Indonesia. Jakarta: LP3ES : Prakarsa.

Sitorus, Agnes Vera Yanti dan Arsani, Ade Marsinta (2016). Komparasi Pertumbuhan Ekonomi Inklusif Di 33 Provinsi Indonesia Tahun 2010- 2015: Studi Kasus Menggunakan Metode Pendekatan ADB, WEF, DAN UNDP. Jurnal Perencanaan Pembangunan. 64-77

Sukirno, Sadono. (2006). Pengantar Teori Makro Ekonomi. Jakarta: Raja Grafindo Persada.

Thirwall, A. P. (1986). Growth and Development. Hongkong: Macmillan Education Ltd.

Todaro, Michael P. (1998) Pembangunan Ekonomi. Jakarta. Erlangga. 